\title{
Antiinflammatory effects of apoptotic cells
}

\author{
Peter M. Henson and Donna L. Bratton
}

Program in Cell Biology, Departments of Pediatrics and Immunology, National Jewish Health, Denver, Colorado, USA.

\begin{abstract}
Apoptotic cells are rapidly phagocytosed by macrophages, a process that represents a critical step in tissue remodeling, immune responses, and the resolution of inflammation. In 1998, Peter Henson, Donna Bratton, and colleagues at National Jewish Health demonstrated that phagocytosis of apoptotic cells actively suppresses inflammation by inhibiting the production of inflammatory cytokines and inducing production of antiinflammatory factors, including TGF- $\beta$ and prostaglandin E2. Here they discuss the evolving relationship among apoptosis, phagocytosis, and inflammation.
\end{abstract}

In the course of our longstanding investigation of the inflammatory response, in the early 1980s we began to focus on its normal resolution, especially on the disposition of the accumulated granulocytes. This led to showing removal of "effete" neutrophils by uptake into macrophages (1). The observation was, in effect, a re-recognition of Metchnikov's observations of macrophages phagocytosing microphages in the 1890s. The arrival in our program of Chris Haslett, who had worked previously with Andrew Wyllie, brought appreciation that the target cells were in fact undergoing apoptosis (2), a form of programed cell death (PCD) previously described in the now-classic 1972 paper by Kerr, Wyllie, and Currie (3). Addressing the question of how apoptotic cells were recognized as "foreign" enough to initiate their phagocytosis led a graduate student in our laboratory, Valerie Fadok, to the key observation that exposure of phosphatidylserine (PS) on the outer membrane leaflet of apoptosing cells was an important recognition ligand (4). A subsequent search for PS "receptors" revealed a complex and highly redundant group of structurally unrelated molecules that bind to PS and contribute to apoptotic cell uptake (5). Importantly, during the same period in the 1980s, Bob Horvitz and colleagues carried out a series of elegant genetic studies in C. elegans that revealed a set of unique signaling pathways involved in uptake of dying (apoptotic) cells by neighboring cells as a closely orchestrated component of normal nematode development (6). These pathways were shown to be highly evolutionarily con-

Conflict of interest: The authors have declared that no conflict of interest exists.

Citation for this article: J Clin Invest. 2013; 123(7):2773-2774. doi:10.1172/JCI69344 served across metazoa, including mammals, during development, tissue remodeling, and removal of inflammatory cells.

In a 1998 paper published in the JCI (7), we demonstrated that interaction of active suppression of their inflammatory mediator production (Figure 1A). This contributed to the current understanding of apoptotic cells as being generally antiinflammatory (inflammosuppressive) and also immunosuppressive. It also emphasized the active role played by apoptotic cell recognition in the resolution of inflammation: not only removing the inflammatory cells, but also turning off the mediators that attracted them in the first place. This was exemplified in a follow-up JCI paper in which we showed early resolution of pulmonary inflammation by deliberate application of PS-exposing apoptotic cells (8). Naturally, these studies did not arise in a vacuum. Earlier work in nematodes and mammals clearly demonstrated that apoptotic cells were removed locally in tissues by "silent" processes that did not induce local reactions in the tissue or initiation of proinflammatory mediators (9). This was reflected, for example, in the normal, almost invisible removal of $>10^{11}$ neutrophils per day from the adult human circulation! Uptake of apoptotic cells was thereby contrasted to other forms of phagocytosis (foreign organisms) and set the stage for demonstration that the removal was not merely silent, but actively antiinflammatory, both in the above-mentioned paper as well as by Voll et al. (10). It also soon led to the recognition that apoptotic cells remain physically intact long enough for this removal to occur before membrane dissolution and the release of potentially inflammatory and immunogenic intracellular contents. The dualmacrophages with apoptotic cells led to ism between apoptosis and necrosis and their effects is now generally recognized, although both terms were originally coined in the context of tissue pathology. Again, the scientific climate at the time was ripe for these concepts, including (a) the importance of cell removal during development and the resolution of inflammation; (b) recognition of roles for innate immunity, pattern recognition, and response to dying cells in fine-tuning the adaptive immune response; and (c) the somewhat oversimplistic teleologic concept of different forms of cell death, being either "good" (apoptotic and silent) or "bad" (necrotic, proinflammatory, and proimmunogenic).

The original experiments implicated the multifunctional mediator TGF- $\beta$ in this inflammosuppression, as well as prostaglandin E2 ( $\left.\mathrm{PGE}_{2}\right)$, which was later shown to result in part from secondary effects of TGF- $\beta$ (11). TGF- $\beta$ has become a wellknown contributor to multiple tissue processes, from blockade of inflammatory mediator production to complex shaping of immune responses, alteration of epithelial functions, and induction of fibrosis. As such, its induction in response to the recognition of apoptotic cells brings to the fore a process that is far from silent and that has much broader potential roles in normal tissue remodeling, modulation of the immune response, and induction or suppression of neoplasia and metastasis (Figure 1B).

Many questions concerning the antiinflammatory effects of apoptotic cells remain. For example, while blockade of PS on the apoptotic cell surface prevents many of the antiinflammatory consequences, the spectrum of PS "receptors" involved in these responses is not at all clear. Because actual uptake of the apoptotic cell is not required for the inflammosuppressive switch, receptors signaling for these two different effects may be distinct. It has also become increasingly clear that there is substantial heterogeneity in PCD/apoptotic processes (12), and it is likely that different forms of PCD will lead to different responses from the responding cell. Here too, it appears that the recognition and response to apoptotic cells is more general and by no means confined to the monocyte- 
A

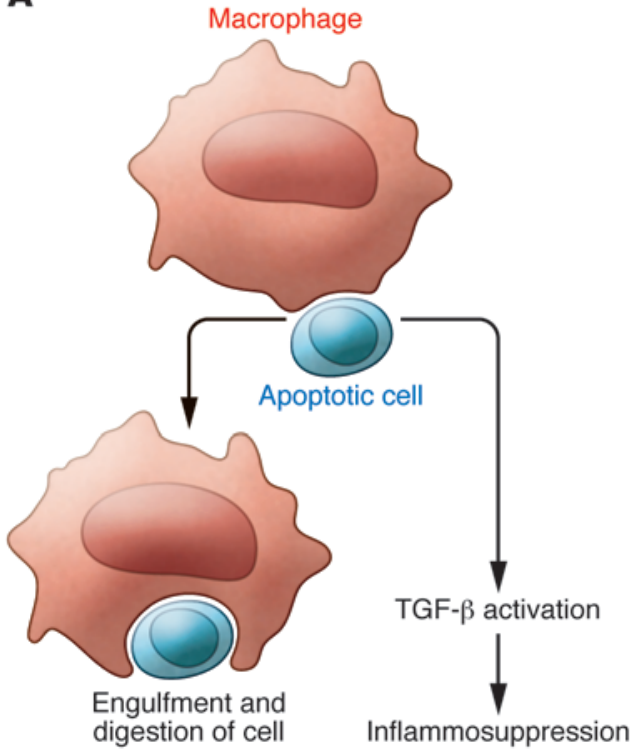

B

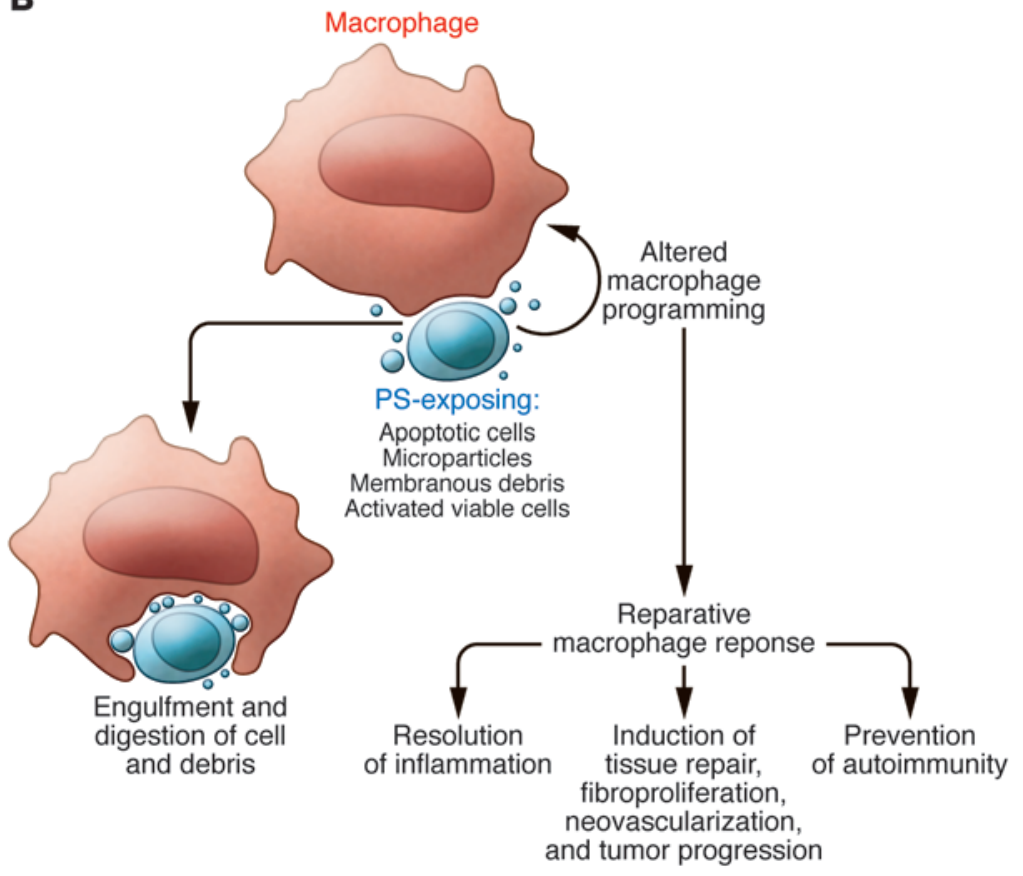

\section{Figure 1}

Responses of macrophages to recognition of apoptotic cells. (A) The antiinflammatory effects outlined in the 1998 JCl paper (7). (B) An outline of the broader concepts of such responses as seen 15 years later.

macrophage or dendritic cell lineages. Further, while TGF- $\beta$ seems to be an important mediator of the response to apoptotic cell recognition, the effects on macrophages or other responding cells are now known to be much more complex, involving not only production of other suppressive and tissuereparative mediators, but also alteration of intracellular signaling pathways. A critical concept here is that these responses lead to significant reprograming of the macrophage, with broad functional consequences for its action in the tissues.

The increasing recognition that macrophages derive from two quite different ontological sources and are highly plastic with regard to their programing in different tissue environments (and, we hypothesize, shaped in part by exposure to apoptotic cells or cells exposing PS as part of their activation responses) opens up a fascinating field for study of dynamic effects of apoptotic cells in both normal tissue maintenance and circumstances of injury and infection (Figure 1). The importance of these processes also clearly raises questions regarding the consequences of abnormalities or blockade of apoptotic cell recogni- tion and removal, as altered response to apoptotic cells clearly contributes to a host of diseases, including tissue destruction, as in emphysema, and/or autoimmunity, as in systemic lupus erythematosus.

\section{Acknowledgments}

The authors are supported by USPHS research grants HL81151, HL34303, and AI58228.

Address correspondence to: Peter M. Henson, Department of Pediatrics, National Jewish Center, 1400 Jackson St., Denver, Colorado 80206, USA. Phone: 303.388.4461; Fax: 303.398.1381; E-mail: hensonp@njhealth.org.

1. Newman SL, Henson JE, Henson PM. Phagocytosis of senescent neutrophils by human monocytederived macrophages and rabbit inflammatory macrophages. J Exp Med. 1982;156(2):430-442.

2. Savill JS, Wyllie AH, Henson JE, Walport MJ, Henson PM, Haslett C. Macrophage phagocytosis of aging neutrophils in inflammation. Programmed cell death in the neutrophil leads to its recognition by macrophages. J Clin Invest. 1989;83(3):865-875.

3. Kerr JF, Wyllie AH, Currie AR. Apoptosis: a basic biological phenomenon with wide-ranging implications in tissue kinetics. Br J Cancer. 1972;26(4):239-257.
4. Fadok VA, Voelker DR, Campbell PA, Cohen JJ, Bratton DL, Henson PM. Exposure of phosphatidylserine on the surface of apoptotic lymphocytes triggers specific recognition and removal by macrophages. J Immunol. 1992;148(7):2207-2216.

5. Gardai SJ, Bratton DL, Ogden CA, Henson PM. Recognition ligands on apoptotic cells: a perspective. J Leukoc Biol. 2006;79(5):896-903.

6. Hengartner MO, Horvitz HR. Programmed cell death in Caenorhabditis elegans. Curr Opin Genet Dev. 1994;4(4):581-586.

7. Fadok VA, Bratton DL, Konowal A, Freed PW, Westcott JY, Henson PM. Macrophages that have ingested apoptotic cells in vitro inhibit proinflammatory cytokine production through autocrine/ paracrine mechanisms involving TGF-beta, PGE2, and PAF. J Clin Invest. 1998;101(4):890-898.

8. Huynh ML, Fadok VA, Henson PM. Phosphatidylserine-dependent ingestion of apoptotic cells promotes TGF-beta 1 secretion and the resolution of inflammation. J Clin Invest. 2002;109(1):41-50.

9. Meagher LC, Savill JS, Baker A, Fuller RW, Haslett C. Phagocytosis of apoptotic neutrophils does not induce macrophage release of thromboxane B2. J Leukoc Biol. 1992;52(3):269-273.

10. Voll RE, Herrmann M, Roth EA, Stach C, Kalden JR, Girkontaite I. Immunosuppressive effects of apoptotic cells. Nature. 1997;390(6658):350-351.

11. Freire-de-Lima CG, Xiao YQ, Gardai SJ, Bratton DL, Schiemann WP, Henson PM. Apoptotic cells, through transforming growth factor-beta, coordinately induce anti-inflammatory and suppress pro-inflammatory eicosanoid and NO synthesis in murine macrophages. J Biol Chem. 2006;281(50):38376-38384.

12. Green DR. The end and after: how dying cells impact the living organism. Immunity. 2011; 35(4):441-444. 